\title{
GeNOCIDE AND THE HEALING PROFESSIONS
}

\section{Michael DUdLey AND Fran GALE ${ }^{1}$}

Nazism is not a closed episode. Like nuclear war and environmental destruction, it warrants universal concern. The professions in general, and the mental health and helping professionals in particular, have played key roles in waging the 'war on terror'. In 2007, a British doctor attempted to bomb Glasgow airport. Dr Che Guevara, Dr Radovan Karadzic, and those supporting Hamas provide examples of doctors or psychiatrists allied to state violence, as shown below and by Kaplan and Walter in this volume. Though it is imperative that helping professionals ponder professional abuses and their origins, contemporary bioethics generally neglects this record. ${ }^{2}$ Individual professionals may exploit patients in a manner universally regarded as criminal or in breach of codes, but may also follow political-institutional or state-based rules without necessarily knowing (or perhaps 'knowing' - that is, they are denying at some level) that their behaviours are abusive. Such systemic abuses frequently involve loyalties divided between patients and third parties in this case, the state.

In this contemporary setting, we examine the actions of Nazi doctors and psychiatrists, the lasting outcomes of the Nuremberg medical and other trials for both human rights and mental health, and most significantly, the motives and reasons for three kinds of behaviour: harming, standing by,

1 This is a revised version of the chapter 'Through a Glass, Darkly: Nazi era illuminations of psychiatry, human rights and rights violations' that appears in their book, Dudley, Michael, Silove, Derrick and Gale, Fran (eds) (2012), Mental Health and Human Rights: Vision, praxis and courage, Oxford, Oxford University Press.

2 Caplan (2007), 70-71. 
and rescuing.

We chose the Holocaust because of its historical significance for human rights, and because it is a 'pure case' of genocide that has been researched in immense detail. The Holocaust is instructive about the causes and remediation of human rights abuses. Two motivating questions arise: first, what prevents today's doctors, psychiatrists and helping professionals falling from grace in comparable ways?; second, given the Holocaust's interplay of individual, situational and social factors, where should the emphasis in prevention lie? The answers matter greatly for states, institutions, and professional and other communities that must safeguard against recurrence.

\section{The contemporary setting: human rights abuses specific to mental health}

The 'war on terror' has damaged the human rights achievements that followed World War II. America's Bush administration 'achieved' this through 'rendition' of suspects to places of torture, by undermining the International Criminal Court, and by using notorious centres like Guantanamo Bay and Abu Ghraib prison, the former site of Saddam Hussein's tortures, murders and experiments. ${ }^{3}$

Many investigations into Abu Ghraib demonstrate that it was overcrowded and unsewered, and its staff and prisoners frequently killed or traumatised by constant shelling. Sweeps and checkpoints collected blameless civilians and families, and fear of their joining the insurgency and absence of administrative authority foiled their release. Missing was leadership by its new, inexperienced commander and other principals; staff training, supervision, accountability and coordination; and any capacity to care for prisoner children and

${ }^{3}$ Ehrenfreund (2007), 209-13. 
inmates with contagious diseases or mental illness (Zimbardo 2007).

Frustrated higher commanders determined to extract 'actionable intelligence' from suspected insurgents. Major General Geoffrey Miller, visiting from Guantanamo Bay, stated he wanted Abu Ghraib's prisoners 'treated like dogs' (Karpinski 2004; Karpinski 2005). Post-Korean war programs, developed to enable military personnel to survive interrogations, were modified. They included long-term isolation, threats, exploitation of phobias, inducement of fear (among others, through the use of dogs), severe humiliation, including demeaning and sometimes sexual assault, degrading 'trophy photography' and sleep deprivation ${ }^{4}$ (Sontag, 2003; Bloche and Marks, 2005). Both military and civilian suspects were held indefinitely, and their Geneva Convention rights to fair trial and freedom from 'cruel, inhuman and degrading' treatment were brushed aside. Abu Ghraib's civilian interrogators were anonymous and lawless, sometimes killing with impunity.

Philip Zimbardo rejects the emphasis on individual character, inevitably the official explanations which blame the 'bad apples', a minority of low-ranking individuals. Instead, he highlights situational and wider social contexts - the 'bad barrel' and 'bad barrel-makers' respectively. His interviews with Sergeant Chip Frederick, a key operations manager whom he was asked to help defend, reveal that untrained army reservists, despised by fellow soldiers, committed the abuses. Lack of actionable intelligence led to further pressure to break prisoners. Frederick, who previously acted as a guard in a low security prison, had no record of violence or antisocial behaviour, and his personality testing was unremarkable. Yet he was responsible for attaching electrodes to a hooded prisoner who was forced to stand on a box and

4 Zimbardo (2007), 362-65. 
told that if he moved he would be electrocuted. While Frederick received a severe sentence, heads of state and senior 'architects'-politicians, lawyers, security chiefs, military leaders, and medical personnel-escaped prosecution. ${ }^{5}$ US Department of Defense documents show that health professionals worked in behavioural science consultation teams to facilitate coercive interrogations. They formulated general and individual interrogation approaches, allowed interrogators to exploit detainees' medical records, certified detainees' fitness, monitored interrogations, falsified medical records and death certificates, failed to report abuses and to provide basic medical care (Miles 2004). Abu Ghraib's psychiatrist was employed not to meet the needs of staff or mentally ill detainees, but to help make interrogations more effective. ${ }^{6}$

Not only did the higher command not authorise and check tactics, but directives for health professionals diverged markedly from recognised human rights standards. Some argued that as they were not operating as clinicians, patient ethical codes did not apply. Ethical guidelines from the US Presidential Task Force on Psychological Ethics and National Security did not prohibit psychologists' participation, nor require their adherence to international human rights law regardless of interpretation by military authorities (Bloche and Marks 2005). The American Psychological Association initially endorsed interrogation up to a 'sub-torture threshold', and was accused of dispensing with traditional ethical standards outside the strictly therapeutic context by separating clinical from non-clinical duties. But such coercive, deceptive procedures depart from the doctor-patient relationship with its precondition of voluntary, informed

5 Zimbardo (2007), 324-443.

${ }^{6}$ Zimbardo (2007), 362. 
consent. Even if physicians did not participate directly, their presence legitimated and sanitised it. The American Psychiatric Association stated that not only should psychiatrists not participate in torture, but should not be part of interrogations; and that they have a responsibility to report situations of torture. Moreover, there is no indication that doctors have the kind of skills that are useful in interrogation.

\section{Enduring legacies of the Holocaust}

The Nazi era is the nadir of modern Western history. At its heart are six million Jewish victims, and 23 million others, ${ }^{7}$ actions so enormous, cruel and intricate as to defy credulity. Surviving and remembering such unalloyed evil forever changes feeling, thinking, imagination and memory (see Levi 1987; Higgins 2003, 2006). The death camps were another universe, defying speech (Adorno 1955) and commanding, at least initially, only silence in the face of it all. SS militiamen taunted their prisoners with the prospect of denial and disbelief as they worked to destroy all traces of evidence. In Terrence Des Pres' book The Survivor: An anatomy of life in the death camps (1976), a guard says to an inmate that even if he survives to tell the tale, no one will believe him. Fortunately, if that be the word, the Holocaust is a thoroughly documented historical event, as well as a universal symbol for radical evil, and a yardstick for crimes against humanity (Alexander et al 2009). US Prosecutor Robert Jackson stated in his opening address at the first Nuremberg trial: 'The wrongs which we seek to condemn and punish have been so calculated, so malignant and so devastating that civilisation cannot tolerate their being ignored because it cannot survive their being repeated.'

7 Among others, 8.2 Russian civilians, 5.9 million Ukrainian civilians, 3.5 to 5 million Russian prisoners of war, 3.5 million Poles, 220,000 Romani, 22,000 anti-fascists, 15,000 Serbian partisans, 15,000 homosexual men, and 5,000 Jehovah's Witnesses. The Nazi allies, the Croatian Ustasa, killed 200,000 Serbs. 
Mirroring and harnessing Western modernity, Nazism used technology and bureaucracy to pursue its ideologicallydriven, murderous racism (Bauman 1989; Bauer 2001). Its economic, environmental and public health emphases are familiar, captivating and confronting (Dudley and Gale 2002). Holocaust analysts divide populations by their responses: perpetrators (numbering around two million), bystanders (numbering hundreds of millions), and rescuers, maybe a few tens of thousands (Bauer 2001). These categories, while heuristically useful, are not watertight. Bavarian peasants, for example, traded with Jewish cattle dealers despite Nazi attempts to prevent this, yet often approved antisemitic laws. ${ }^{8}$ In the camps' 'grey zone', victims sometimes were accomplices (kapos, for example) to perpetrators, though perpetrators were not victims (Levi 1987). Despite the Nazi state's genocide and criminality, the actors were neither angels nor demons, but ordinary people (Bauer 2001; Browning 1998). Holocaust remembrance continues for victims and survivors, and for nations, communities and professions to prevent amnesia and protect against recurrence.

\section{Nazi doctors and psychiatrists: activities}

A particular breach of trust occurs when physicians abandon their special responsibilities (Grodin and Annas 2007; Annas and Grodin 1992). That doctors act as architects, leaders, instruments and auxiliaries of mass murder, conducting lethal experiments on behalf of a transgressor state, may beggar belief: yet after World War II, prosecution investigators at the Nuremberg and other medical trials exposed and thoroughly documented such activities on a large scale (Alexander 1948, 1949). The transgressions of doctors, psychiatrists and other professionals under Nazism have been extensively examined

${ }^{8}$ Kershaw (2000), 193. 
(see Grodin and Annas 2007, Schmidt 2007, Weindling 2006, Baum 2008, Dudley and Gale 2002 and Markusen 1997 for examples of recent bibliographies). Such a debacle was unprecedented. Education and professional status, rather than conferring immunity, generally facilitated the Nazi agenda. Medicine in particular was united to the Nazi state, with psychiatry the chief medical specialty represented in the killing programs, without whom the Holocaust may well have failed (Dudley and Gale 2002; Markusen 1997).

As the Nazis removed moral restraints, they quickly ceased to ratify advanced Weimar republic legislation on human experimentation (Hanauski-Abel 1996). Clinicians and scientists decisively abandoned medical and psychiatric ethics when they promoted and participated in compulsory sterilisation. Doctors, psychiatrists, welfare, church and community groups supported the 1933 law which required mandatory and widely-enforced reporting. Lawyers, doctors and psychiatrists manned courts which heard cases in secret and allowed few successful appeals. The law encompassed those suffering from schizophrenia, manic depressive insanity, hereditary epilepsy, alcoholism, and Huntingdon's chorea, as well as hereditary blindness, hereditary deafness, severe deformity (including talipes, club feet), and congenital feeble-mindedness. The last, a vague, flexible category, captured social deviance (such as prostitution under 'moral feeble-mindedness'), and accounted for three-quarters of cases, including many in poverty. Sterilisation also allowed asylum directors to discharge patients and cut costs. Many patients died of surgical complications. ${ }^{9}$

From 1939 in occupied Poland, adults with mental disabilities were killed by poison gas, the first trial of this method. In Germany, doctors, psychiatrists, nurses and other helping professionals and staff joined with administrators in

${ }^{9}$ Lifton (1986), 25; Bock (1997), 161-62; Evans (2006), 507-11. 
the Tiergartenstrasse (T4) 'euthanasia' program for children. Gassing was extended to adults with mental disabilities. Hitler's signature appears on the T4 program on his private letterhead. ${ }^{10}$ The criteria for killing were both 'eugenic' (including 'non-Aryan') and economic, related to potential productivity, but in practice the victims were sacrificed for quotas and administrative efficiency. As an open secret, which claimed 200,000 victims, 'euthanasia' had many accomplices: the myth of a small group of fanatical perpetrators hoodwinking a public who knew nothing is untenable ${ }^{11}$ (Friedlander 1995; Bauer 2001). That these institutions of intentional killing bore the insignia of the Red Cross on their rooftops is an indictment of both the German Red Cross and the International Commission of the Red Cross - which never disavowed or disaffiliated its German colleagues.

This dress rehearsal provided senior expertise to killing centres in the occupied territories, for the so-called ' $14 \mathrm{f} 13$ ' program that claimed approximately 50,000 concentration camp victims (Lifton 1986). ${ }^{12}$ From mid-1941, doctors and psychiatrists oversaw the 'Final Solution', manning camps, performing executions and selections and providing ideological justifications ${ }^{13}$ (Lifton 1986). In all phases, they exploited the murdered and the living for medical research. Coerced inmates underwent at least 26 types of experiments, including ice-water immersion, high altitude decompression, high-dose radiation, and making seawater drinkable, and often died in the search for better killing methods or through

10 Kershaw (2008), 40.

${ }^{11}$ Evans (2006), 507-11; Evans (2009), 72-101.

12 Schmidt (2007), 271.

13 Proctor (1992), 27. 
callous disregard. ${ }^{14}$ While most experiments were scientifically useless, ${ }^{15}$ the possible exceptions (hypothermia and decompression) raised sharp ethical questions about using knowledge obtained by such means (Moreno 2007; Müller-Hill 1988). Professor Louis Waller, an esteemed Australian legal authority, raised this question in 1985 under the illuminating title of 'The Fruit of the Poisoned Tree'. ${ }^{16}$

The motives of perpetrators - among which peer pressure, duress, authoritarianism, careerism and ideology featured prominently-are explored below. Specifically, Nazi pseudoscience ('race hygiene', 'scientific racism' and eugenics) and its biomedical engineering project for a judenrein utopia, dovetailed perfectly with the experimental ambitions of scientists, doctors and psychiatrists, whose careers prospered. Few psychiatrists resisted and no letters survive from psychiatrists on behalf of their patients to the authorities (Dudley and Gale 2002). As noted, nurses (McFarland-Icke 1999) participated in killings, while psychologists (Mandler 2002) were also implicated in the Nazi debacle.

When the war ended, the ensuing trials and plethora of psychiatrist and physician suicides sullied the reputation of German medicine. An American denazification report estimated that about half of German physicians were 'proven Nazis' - about 24,000, against the profession's later view of only 350 criminal doctors. ${ }^{17}$ What had gone wrong, and how, was too complex for a trial which piloted new international law. ${ }^{18}$

Doctors and medical scientists denied complicity by

14 Caplan (2007), 67; Schmidt (2007), 160ff.

15 Weindling (2006), 4.

16 Halm (1985), 95-100.

17 Weindling (2006), 38-39.

18 Schmidt (2006), 3, 168. 
representing themselves as victims of Nazism. Unrepentant Nazis, conservatives, and leading physicians disparaged the trials as 'victors' justice', and suppressed publications by the trial's medical observers. ${ }^{19}$ German medical associations avoided examining their Nazi past (Pross 1992; Kater 1997) and exonerated individuals by blaming socialised medicine and excessive state powers, while insisting on professional autonomy. ${ }^{20}$ Cold War priorities (strategic research and intelligence) also protected those who were implicated. (Contemporaneously, the United States gave Japanese Unit 731 - which also conducted biological warfare experiments accounting for 270,000 victims-immunity from prosecution). ${ }^{21}$ In the 1980s, a research-granting agency which funded Robert Ritter's project (see below), refused to acknowledge that its precursor financed the genocide. ${ }^{22}$ Medical institutes and researchers used materials from murdered victims before this was outlawed and the remains reburied in 198923 (Hanauski-Abel 1996). Nazi influence also affected the World Medical Association, which virtually ignored the Nuremberg Code (Kater 1997). ${ }^{24}$

\section{Human rights outcomes of the Nuremberg trials}

The post-war Nuremberg trials of the Nazi leadership (19451949) were landmark events, defining new standards of international justice with far-reaching significance for human rights. An International Military Tribunal defined crimes such as conspiring against peace, waging aggressive war, and a

19 Weindling (2006) 5, 39, 43, 211-17.

20 Weindling (2006), 6; Schmidt (2007), 266.

21 Weindling (2006), 309, 342.

22 Müller-Hill (2007), 59.

${ }^{23}$ Müller-Hill (2007), 61.

${ }^{24}$ Schmidt (2007), 266. 
new category, crimes against humanity, and tried the former Nazi military leaders for these and for war crimes. The trials of Nazi doctors, the Einsatzgruppen (the four mobile killing squads), jurists and industrialists, the war crimes trials in the separate zones of occupation, and national prosecutions in various German-occupied countries followed (Ehrenfreund, 2007). All four occupying powers exercised sovereignty and tried the Germans accused for crimes against pre-Nazi German law.

The trials overthrew, at least partially, the principle of national sovereignty - established by the Treaty of Westphalia in 1648-which bestowed immunity on state functionaries within state borders. States and other authorities could not wilfully disregard individuals' rights. The trials also demolished the defence of superior orders, and the tu quoque ('you did it too') defence, thus re-asserting the principle of individual moral responsibility that had been eroded by authoritarian leadership. ${ }^{25}$ These trials affected the rules of war and treatment of prisoners, and in bridging gulfs of language, nationality, custom and procedure, they proved feasible. The principle of universal jurisdiction held that any country where grave crimes are committed, such actions could be judged and individuals punished. The trials of Nazi industrialists foreshadowed lawsuits against businesses accused of human rights abuses. ${ }^{26}$

Furthermore, the extensive, authoritative documentation of Nazi atrocities "[established] these perceived "incredible" events by clear and public proof, so that no one can ever doubt that they were fact not fable' ${ }^{27}$ These trials in effect inaugurated Holocaust history, belied future Holocaust denial, and shaped German democracy.

${ }^{25}$ Schmidt (2007), 250.

${ }^{26}$ Ehrenfreund (2007), 107-10, 215-19.

27 US Prosecutor Telford Taylor, quoted by Schmidt (2007), 174. 
Raphael Lemkin coined the word 'genocide' to describe the German authorities' systematic murder of ethnic and religious groups defined as degenerate. Arguing that genocide should denote the motivation to commit such crimes, he criticised the new category 'crimes against humanity' for neglecting this motivation. How much the medical trials applied this reasoning is a moot point. ${ }^{28}$ Telford Taylor regarded the experiments as pilot studies for genocide. ${ }^{29}$

The Nuremberg trials - and for medicine, the Nuremberg Code-were three great contemporaneous reforms, together with the formation of the United Nations (1945) and the publication of the Universal Declaration of Human Rights (1948). Collectively, they helped to launch the international human rights movement and frameworks, including the Genocide Convention; to revise the Geneva Conventions on laws and customs of war; and to establish the European Court of Human Rights, the Bill of Rights and subsequent rights treaties and institutions. They are relevant not just for medicine and mental health, but civil society and planetary survival (Robertson 2006; Ehrenfreund 2007).

Notwithstanding, enforcement has been piecemeal. During and after the Cold War, no international machinery underwrote human rights protections. Genocide continued: today, perpetrators in East Timor, the Congo, and Darfur remain free. The United States circumvented international standards in its 'war on terror'. The charge of 'victors' justice' (made by Hermann Göring at Nuremberg) endures: the Allies were not tried for dropping the atom bomb, for example. Nevertheless, the Nuremberg legacy endures in the Pinochet,

${ }^{28}$ Weindling (2006), 3, 102;

${ }^{29}$ Weindling (2006), 5; Schmidt (2007), 161. 
Milosevic, Tadic and Karadzic trials, the advent of the International Criminal Court in 2002, and recent international actions to address genocide - the Kosovo bombings, and the tribunals or special courts for the former Yugoslavia, Rwanda, Sierra Leone and Cambodia ${ }^{30}$ (Robertson 2006).

\section{Positive outcomes from the doctors' trials: the Nuremberg Code and its successors}

While the patient's health and protection from harm date from Hippocrates, informed consent and non-therapeutic experimentation only emerged in 19th century codes of ethics and pre-Nazi (1900 and 1931) German documents that thoroughly discussed these issues (Grodin 1992; Winau 2007).

The Nuremberg doctors' trial ended with a declaration about permissible medical experiments. In Europe and the United States, however, frequent dangerous medical experiments continued. The Tuskegee (Alabama) syphilis experiment which 'examined' the natural progression of the untreated disease on poor, rural, Black men began in 1932 but only ended in 1972 (Reverby 2009). Rediscovery of the 'Nuremberg Code' in the 1960s as the first global, comprehensive reflection on the nature, purpose and limits of human experimentation was vital to identifying and addressing this area ${ }^{31}$ (Perley et al 1992; Grodin 1992).

Pre-eminently, the $\mathrm{Code}^{32}$ requires voluntary informed consent. It mandates qualified researchers, socially beneficial intent, scientific design and results unobtainable by other methods. Benefits must outweigh risks, harm must be minimised, and risk to life prevented (except when researchers experiment on themselves). Subjects must be

${ }^{30}$ Ehrenfreund (2007), 153-96.

31 Weindling (2006), 340-43.

32

http://www.ushmm.org/research/doctors/Nuremberg_Code.htm 
allowed to withdraw at any time. Researcher responsibility for participants' well-being is paramount.

The Code's successors, not comprehensively discussed here, assert the rights of health research participants. They include the World Medical Association's Declaration of Helsinki $(\mathrm{DoH})^{33}$ which has formed the cornerstone of human research ethics. For vulnerable populations like children, prisoners and military personnel, the DoH emphasised physician responsibility ${ }^{34}$ and softened the Code's absolute requirement of voluntary informed consent, instead requiring consent by legal guardians ('responsible relatives' for children; minors should consent where possible). Nevertheless, the first DoH revision (1975) confirmed that the interests of science and society should never take precedence over the well-being of the subject (para III 4), and decreed that research ethics committees (or their equivalent) must oversee research, initiating what is now widespread practice (Williams 2008).

The Council for the International Organisation of Medical Sciences (CIOMS), formed by World Health Organisation (WHO) and UNESCO, also developed the International Ethical Guidelines for Biomedical Research Involving Human Subjects (1982; CIOMS-WHO 1993), which despite some inconsistencies with DoH (Macklin 1999), were also informed by the Code. In communal and non-Western research settings, they noted difficulties with informed consent, research knowledge, funding and governance (Perley et al 1992). Successive DoH revisions have fired controversies about principled versus pragmatic approaches to research ethics in the developing world (Lurie and Wolfe 1997; Lie et al 2004;

33 (1964), revised (1975), (1983), (1989), (1996), (2000), (2008), with clarifications (2002), (2004).

${ }^{34}$ Schmidt (2007), 283. 
Social Medicine Portal 2008; Rennie 2008; Sharma 2004).

\section{Harming by individuals and groups: social, situational and individual contributions}

Like other great evils, the Holocaust was inhuman, yet humans were responsible for systematic attacks on humans. The social science lexicon rarely discusses evil, and behavioural scientists and clinicians reluctantly examine it, thus magnifying its apparent incomprehensibility. Some consign evil to the province of philosophers and theologians, or alternatively (and positivistically) reduce it to behaviour, biology or mental illness. This dishonours those with a genuine mental illness and relieves culprits of responsibility (Rosen 2011). The political and military elite of the Third Reich rarely suffered overt mental illness, though the fact that these were 'ordinary men' does not mean they were mentally healthy. Clinical science cannot exclude (im)moral acts from its purview, nor reduce them to judgements about (ab)normality. Like morality, it assays not just events and causes, but who we are, should be, and take ourselves to be (Glas 2006). Patients may interpret professional neutrality on such matters as indifference.

Evil encompasses moral wrongness as an end (the intent to harm) or a means to an end, and extreme harm, through acts disproportionate to any instigation or provocation. Bandura (1975) refers to 'moral disengagement', which involves suspending proactive humane behaviour and abandoning restraints on harmful behaviour. Some note the persistence of such acts, victims' helplessness, levels of perpetrator responsibility, and sometimes the 'magnitude gap' between damage to victims and benefits accruing to perpetrators (Berkowitz 1999; Hamilton and Sanders 1999). ${ }^{35}$ Omission may also be evil (as discussed in Colin Tatz's essay in this volume on the churches during the Holocaust). Card's

35 Staub (2003), 47-51. 
definition ${ }^{36}$ of evils as 'foreseeable intolerable harms produced by culpable wrongdoing' leaves open the question of intent, which may be complex, even impenetrable. ${ }^{37}$ Noting humanity's potential for good and evil, this perspective bypasses essentialist dichotomies.

\section{Motives and reasons for harming, with particular reference to the Nazi example}

As suggested above, recurring individual, socio-cultural and situational factors contribute to mass human rights violations. Holocaust history, other genocides (not considered in detail here), and experimental psychology reveal this. Theories about Nazi doctors and psychiatrists' actions must not only consider these levels of action, but the wider German national situation. In the following sections, the Nazi example and experimental evidence are reviewed to shed light on motives and reasons for harming, bystanding and helping. To direct prevention, it is also important to decide where the 'engineroom' is located.

\section{Personality}

Early researchers considered innate characteristics. In 1955, Adorno and colleagues described the 'authoritarian personality'-characterised by conventionalism, authority submission, aggression, projection and anti-introspectionself-selecting for the Party and the SS. Rather than one (authoritarian) Nazi personality, unsurprisingly a wide range exists. For example, Robert Lifton describes SS doctor Josef Mengele's scientific detachment, flamboyance and fanatical cruelty; chief Auschwitz doctor Eduard Wirths' meticulousness and obedience; gynaecologist and mass

${ }^{36}$ Card (2002), 3.

37 Staub (2003), 49. 
steriliser Carl Clauberg's arrogant ambition. A frequent theme, noted with Lifton's [anonymous] doctor Ernst B, and Gitta Sereny's 1974 study of Franz Stangl (the commandant of Treblinka) and her 1995 biography of Albert Speer (Hitler's architect and from 1942 munitions/armaments minister), is of people emotionally starved or abused as children, struggling to make human connections and seeking liveliness in movements of national regeneration. Stangl feared resistance and was intimidated. Despite Speer's burden of guilt, his wish for transformation and to make amends, his narcissism prevented him empathising with the humanity of his slave labourers or the Jews whom he saw deported from Berlin, and even reciprocating the love of those close to him (Sereny 1998; Kubarych 2005). Speer's problem with denial is treated below.

Adorno and colleagues, however, postulated a relationship between authoritarian personality and the group and/or social environment. ${ }^{38}$ Studies of mass human rights violations highlight how cultures of obedience-whether populist, authoritarian, collectivist or fundamentalist-reject social diversity and dissent. Frequently male-dominated, they avoid critical thinking, prize loyalty, honour and death for the group, and identify and punish their enemies. Institutional and informational control, indoctrination, creating fear and agonising uncertainty, destruction of family and social bonds, and brainwashing children (for example, as soldiers) all enable radical, utopian actions: violence against family, intimates, and moral codes (Glover 1999; Cohen 2001; Pina e Cunha et al 2010). Women are often particularly vulnerable. ${ }^{39}$ Adorno and colleagues' observations about the dynamic interaction between individuals and German culture are highly pertinent. While individual doctors and scientists were centrally responsible, sponsored by the Nazi state, the failure of German society and institutions and the force of situations

38 Baum (1998), 2.

${ }^{39}$ Baum (2008), 29, 48-49 
and social roles must also be understood.

\section{Interplay between personality, group, situational and social determinants}

In Nazism, personality and situational determinants both contributed to the outcome of racist ideology. Hitler is the most striking example in point. In the 'historians' debate' in the 1980s (Mason, 1989), intentionalists like Lucy Dawidowicz (1975) emphasised the importance of Hitler's master plan as expressed in Mein Kampf, while functionalists minimised Hitler's role. They stressed anarchic forces, such as opportunism from Nazism's lower ranks, and bureaucratic chaos and infighting which drove improvisation and increasingly radical agendas (for example, Browning 1998, 2004). A more nuanced synthesis of intentionalism and functionalism now prevails (Bauer, 2001). Thus, Hitler's charismatic authority, according to Kershaw (2008), backed actions, however radical or inhumane, which furthered his ideological obsessions. His non-intervention style permitted party bosses, bureaucrats and professionals full scope for initiative. Since opportunities abounded for expansion, power, status and enrichment, there was never any shortage of chaotic rival schemes or willing participants. One might denounce neighbours to the Gestapo, slur a business competitor's 'Aryan' credentials, or nominate patients for the euthanasia program: this was all 'working towards the Fuhrer' (Kershaw 2008; Bankier 1988; Michman 2010). Competitors for Hitler's favour were often not told of rivals' plans, many of which were deleterious to a 'united' purpose.

Adolf Eichmann's rise from obscurity to managing the 'Final Solution' follows this trajectory (Kershaw 2008). In 1963, Hannah Arendt diagnosed Eichmann's 'banality of evil'; his incapacity to introspect and lack of inner language inclined him to unquestioning obedience to his assigned task, like a $\operatorname{cog}$ in a machine. Eichmann was also not devoid of ideological drivers. Though not radically antisemitic as a 
young man, he joined the Party late as a bourgeois careerist and swiftly took on its program (Berkowitz 1999; Cesarani 2006).

Yet the influence of individuals like Hitler on groups and wider society was also inevitably mutual. As we will see, to further pursue their program, the Nazis depended on public adulation or inertia and lack of resistance.

Socio-cultural and national-historical factors

Socio-cultural and national-historical factors contribute significantly to mass human rights violations. ${ }^{40}$ At a personal or cultural level, tribalism and ethnic nationalism can nurse old narratives that maintain enmity. Past victimisation, enduring wounds, even early childrearing may trigger reactive withdrawal or compensatory anger. Severe, persistent life conditions and struggle for resources may frustrate basic needs like security, attachment, positive identity and role, effective control, justice and meaning (Maslow 1987, Silove 2000). When an individual or group's self-concept is vulnerable, setbacks overwhelm collective and personal self-worth. Defensive superiority then forms a compensatory identity that diminishes and scapegoats others. Leaders who share the group's culture, life situations and often unhealed wounds, ${ }^{41}$ may then propagate destructive ideologies to gain followers or consolidate a following (Allport 1954).

From its foundation in 1871, Germany was a weak (and ultimately a failed) state (Moore 1966; Steinmetz 1997; Kershaw 2008; Higgins 2006), and a non-existent state in the Third Reich period, as Franz Neumann (1967) pointed out contemporaneously. Its ideologies of 'race hygiene' and 'scientific racism', and the Great War's bitter legacies, were

40 Zimbardo (2007), 273-75; Staub, (2003), 352-53, 358.

${ }^{41}$ Staub (2003), 302. 
primers for eventual genocide. Defeat, revolution and the Versailles Treaty's war guilt clauses fed the myth that Jews, socialists, Communists and war profiteers stabbed Germany in the back. Colossal reparations, foreign occupation of the Ruhr and hyper-inflation fuelled economic depression and social chaos. Hitler promised to redeem Germany by modernisation, racial purification and imperial conquest. ${ }^{42}$ In the earlier Nazi years, many Germans experienced mystical, exalted states associated with nationalism (Soelle 2001), expressed in the resurgent economy, the spectacle of the Nuremberg rallies, the victories of German athletes at the Berlin Olympics, and Hitler's achievements in foreign affairs (Friedländer 2007). Psychiatrist Carl Jung, who loved pagan symbolism and myth, valorised the German peoples' revitalisation under National Socialism. ${ }^{43}$ With the coming of the Third Reich, however, state deliberative decision-making also completely disappeared, civilised standards collapsed, and barriers to state-sanctioned inhumanity were rapidly removed (Mommsen 1997; Kershaw 2008). Race hygiene replaced social and sexual health clinics. Waves of repression and violence descended on Jews and other minorities. Political opponents held in the new Dachau concentration camp were murdered (Evans 2004; and Lifton). ${ }^{4}$ Most Germans were insulated from the experience of these groups.

The role of antisemitism is disputed. Earlier historians traced a lineage from Luther through Christian antisemitism to the Third Reich (for example, McGovern 1973). Several authorities suggest that antisemitism was weaker in Germany than in other western countries, like France, and certainly weaker than in eastern Europe. For instance, from

42 Kershaw (2008), 20.

${ }_{43}$ Noll (1997), 264.

${ }^{44}$ Lifton (1986), 25. 
emancipation in 1848 till the Weimar Republic, German Jews did not die of antisemitic violence. During the Weimar period, polarisation occurred between Jewish integration and intensifying antisemitism among various organisations and political parties, especially just after World War I and the years immediately preceding the Third Reich, but not the period in between. From 30 January 1933, a cascade of disastrous policy, legal and social developments overtook Jews (Abrahams-Sprod 2006). Hitler's antisemitism, 'calculation and fanaticism' inspired these developments, and institutions, bureaucracies and professions willingly implemented them. Daniel Goldhagen's controversial 1996 thesis that antisemitism among ordinary Germans was always 'eliminationist' and enabled Holocaust killing has been strongly contested. Some thought it massively simplified and demonised German popular motivations, while others noted the lack of comparison with Nazi-occupied countries, ${ }^{45}$ and as the sole cause of popular participation in genocide it was widely discounted. While antisemitism permeated German national culture, some view Nazi propaganda (at least to 1941) as apparently failing to bolster public support for antiJewish policy and provoking concerns about the illegality of these measures and possible repercussions. Others, like Robert Ericksen (2012), have shown just how complicit the churches and universities were in bolstering the Nazi regime. Ultimately, there was a distancing, an alienation and (from 1941) a buffer between the regime and a war-weary populace, who wanted to know little and who because of their preexistent antisemitic attitudes, did not protest. Thus popular antisemitism may have directly motivated murder but also indirectly and probably more frequently contributed to the radical Nazi program's success by promoting nonintervention, that is standing by in all matters related to Jews (Bankier 1988; Michman 2010; Kershaw 2008). The literature

45 Baum (2008), 27. 
on who knew what and when, on who was complicit or merely companions to this genocide, has been sparse, but is coming into sharp focus with the research of Eric Johnston (2006) and Robert Ericksen (2012).

Bauman (1989) also highlights the Holocaust's origins in modernity, and particularly its trademark: instrumental rationality, which is characterised by segmentation of labour, categorisation and procedures. Although modernity does not explain all genocides, for example Rwanda, ${ }^{46}$ instrumental rationality plays a vital role.

\section{Instrumental rationality, group dynamics and 'othering'}

Thus Bauman notes that administrative or organisational evil depends on deficient ethical frameworks, with efficiency paramount, conscience captive to authority, information diffused, and responsibility fragmented. Attention to task, technique, rules and limited morality separates actions from emotion. ${ }^{47}$ Harms are even easier to commit when one is an intermediary, neither giving orders nor carrying them out (Kilham and Mann 1974), when one is anonymous or disguised $^{48}$ (Staub 2003), and when one is removed from the consequences of one's actions, as modern technological warfare and the Milgram experiments (see below) demonstrate. Eichmann and other 'desk murderers', using the railway tourist fare schedule, could therefore organise 'removal transports' to effect a 'change of residence' of Jewsto Auschwitz. ${ }^{49}$ Bureaucratisation and progressively sophisticated means of killing such as Zyklon-B gas chambers rather than shooting, maximised efficiency and psychological

46 Kershaw (2008), 22.

${ }^{47}$ Cohen (2001), 95.

48 Zimbardo (2007), 297-323.

${ }^{49}$ Glas (2006), 178-79. 
insulation: perpetrators did not face their victims, who became non-human legitimate targets (Browning 1998; Glover; ${ }^{50}$ Russell and Gregory 2005; Bauman 1989, and Rowan Savage in this volume). Each agent's task is plausibly deniable. As a good manager or employee, effective, efficient and legal, one can still (un)wittingly commit evil acts (Adams and Balfour 2004; Pina e Cunha et al 2010). Contemporary examples include international corporations that deal in destruction and death: international small arms traders, the tobacco lobby (Bandura 1999), multinational polluters, and the Hardie asbestos scandal in Australia (Peacock 2009).

Similarly, in overt war, terrorism and genocide, group allegiance and absolution facilitate killing; and situational and group roles, and cultural and organisational arrangements channel the emotions and proclivities of perpetrators. Fundamental needs to survive and belong mean accepting group norms and co-operation (Staub 2003; Zimbardo 2007). Promoting soldiers' connections with comrades also enhances their willingness to act for them and their operational effectiveness against enemies (Grossman 1996).

Interviewing Nazi killers, Lifton and psychiatrist Henry Dicks (1972) underscored their normality rather than pathology.51 Collective, diffused or displaced responsibility allows people to behave more cruelly than if acting alone, to relinquish responsibility for victims' life and welfare, and makes bystander helping less probable. ${ }^{52}$ Christopher Browning, studying the trial documents of Reserve Police Battalion 101, comprising 'ordinary' middle-aged working class men from the social democratic city of Hamburg, emphasised such variables: group and tribal loyalty, peer pressure, assigned roles and obedience to authority. Ordered

${ }^{50}$ Glover (1999), 64-68.

51 Berkowitz (1999), 249.

52 Bandura (1999), 198; Staub (2003), 330. 
to murder Jews in a Polish village (Josefow), the group leader gave his men the choice to opt out, but less than 15 of $500 \mathrm{did}$ so. Not initially heartless, they became progressively desensitised, eventually murdering 70,000-80,000 people (Browning 1998) sometimes bringing their wives and girlfriends to watch their weeks' 'work', and they became the most efficient killers in the Lublin district.

Dehumanisation involves stripping people of human qualities, thus denying likeness, empathy and obligation. Social group research demonstrates that in-groups rate themselves as more human than out-groups and strangers (Haslam et al 2005). Thus moral principles apply to 'us', but not 'them'.53 'Just-world' thinking assumes the world is just, therefore suffering people invited their fate by their actions or character: hence perpetrators devalue people they have harmed (Lerner 1980; Staub 2003). In wars and actions against 'undesirable' minorities, state propaganda portrays enemies as greedy, cruel, godless, raping, murdering, criminal, mindless savages or barbarians or 'gooks', demonic, or dangerous animals (Keen 2004; Glover, 1999; Zimbardo ${ }^{54}$ ).

As Primo Levi's Nazi camp commandant explained, rather than being pointlessly cruel to those who would die, dehumanising victims enabled perpetrators to kill (Levi, 1987). Nazism sought to influence public perception through propaganda films that portrayed Jews, Roma, homosexuals, and people with mental disabilities as vermin or as vicious, lascivious, sinister, grotesque or otherwise subhuman. Such films popularised 'natural selection', and promoted voluntary and involuntary 'euthanasia'. ${ }^{5}$ Blaming victims by staging

53 Staub (2003), 305.

54 Zimbardo (2007), 313.

${ }^{55}$ Gallagher (1990), 92; Friedlander (1995), 88-93. 
incidents where they stand accused as provocateurs (as the Nazis did to Jews on 'Kristallnacht' or Hitler did to Poland at the outbreak of World War II) absolves the perpetrator and justifies further aggression and marginalisation. Zimbardo (2007) shows how institutional power without safeguards leads to abuse. Contagion of emotions may spread with mobs. For some, psychological mechanisms such as sadism, sensational thrill-seeking and threatened egotism may play into this (Baumeister and Campbell 1999). In short, dehumanising people enables torture and murder (see Rowan Savage in this volume).

\section{Language, and the problem with and function of denial}

Denial (specifically knowing yet not-knowing), which operates at personal, cultural and official levels (Cohen 2001), is the sine qua non of mass human rights violations. Denial is literal ('nothing is happening'), interpretative ('what is happening is not what it seems'), volitional ('it's got nothing to do with me'), 'relativist' ('yes, but look at what the Russians did to German civilians'), and so on. ${ }^{56}$

Exculpatory or neutralised language is intrinsic to rights violations. Harms are often justified by invoking higher moral principles (just war theories and rhetoric rationalise making war to resist oppression, save humanity, or secure peace), or by using euphemistic or non-agentic phrases (for example, 'collateral damage', 'surgical strikes', 'friendly fire') (Bandura 1999). Nazi deceptive or distancing language (for example, 'selection', 'special operation', 'resettlement', 'Final Solution') facilitated denial for observers and victims, enabling perpetrators to split off and disown personal acts (Arendt 1963; Cohen ${ }^{57}$ ). The term 'Final Solution' stood for mass murder without sounding like it, keeping the focus on

56 Cohen (2001), 7-9.

57 Cohen (2001), 79. 
problem-solving. ${ }^{58}$

For Hitler, compartmentalisation was vital. Personally, he avoided physical and visual contact with the consequences of his murderous orders, and actively prevented others telling him the truth. Collectively, Hitler strictly separated his life with Himmler, Goebbels, his generals and staff from his intimate personal circle. He also required compartmentalisation by others. A notice on every wall read: 'Every man need only know what is going on in his own domain'. Compartmentalisation involved not only activities but also thinking. Speer observed that linked with his secrecy order, this meant much more than Hitler's wanting people to concentrate their minds - it meant it was dangerous not to ${ }^{59}$ (Kubarych 2005).

Albert Speer exemplifies individual denial. While denying lifelong that he knew the Jews were being exterminated, Speer affirmed that he was blind by choice, not ignorant. Noticing the obvious destruction of 'Kristallnacht' and Jewish evictions, he avoided knowing the reasons. He eluded recognising the barbarous conditions of his slave labourers. A friend advised him never to visit Auschwitz: what he saw there he was not permitted to describe and could not describe. Speer avoided querying him or anyone, evading evidence that would confirm his suspicions that crimes had been committed. He admitted he was 'inescapably contaminated morally; from discovering something which might have made me turn from my course, I had closed my eyes' (Sereny 1996; Kubarych 2005). On tough questions, he generalised about specifics and admitted a little to deny a lot. It was not that Speer did not want to know, but (more strongly) that he wanted not to

58 Zimbardo, (2007), 215; Lifton (1986), 420-55.

59 Sereny (1996), 148. 
know (Kubarych 2005).

German collective denial was expressed and examined after April 1945, when the widely publicised liberation of the Bergen-Belsen concentration camp shocked the world. As events unfolded, many Germans claimed 'We knew nothing about this' (Davon haben wir nichts gewusst). Though Germans knew of Nazi murderousness towards Jews through propaganda (Johnson 2005), awareness of genocide (which began after the invasion of Russia) had come gradually for the Allies and Germans. Except for civilians and soldiers in close proximity to the Einsatzgruppen, the concentration camps in German-occupied lands or extermination camps in Poland, there were rumours and guesses (Sereny 2000). German historian Peter Longerich comments that Davon, meaning 'about this', implies knowledge and unwillingness to openly address the subject further. The verb gewusst, implying knowledge, is carefully chosen, not excluding rumours and partial information that was uncertain. People accordingly employed this strategy to distance themselves from responsibility (Richards, 2006). The Holocaust therefore was an open secret in real time (Cohen 2001). The question of knowledge and accountability has been central to recent German history (see below). After the war, many asserted that Germans had been misled ${ }^{60}$ or were uninformed. Defendants concealed, distorted or justified their roles, for example citing obedience and community loyalty during war ${ }^{61}$ or were selfrighteously indignant. ${ }^{62}$ Neurologist Julius Hallervorden, who removed brains from murdered children with cerebral palsy, told Leo Alexander that 'there was wonderful material among those brains, beautiful mental defectives...[but] how they

60 Schmidt (2007), 268.

${ }^{61}$ Schmidt (2007), 157.

62 Weindling (2006), 161. 
came to me was none of my business' ${ }^{6}{ }^{63}$

\section{Gradualism}

People and societies change for worse (or better) through stepwise actions (Zimbardo 2007; Staub ${ }^{64}$ ). Prefacing big requests with related smaller requests (the 'foot-in-the-door' tactic) is effective (Staub;65 Milgram 1963; Zimbardo 2007). Learning through participation is critical-for harming, gradually inducting and capturing people in practices they normally find morally abhorrent. Thus exposure and stepwise change overcomes resistance, altering values, selfconcept and behaviours. 'Teachers' who shock errant 'learners' increase shock intensity as learner performance declines (Bandura et al 1975). Some observe the role of learned perversity or unleashed sadism, based on an emerging culture of freedom from constraints that is associated with absolute power, or the removal or suppression of negative consequences for undertaking increasingly cruel acts upon others (Rosen 2011).

Under the Nazis, Jewish assimilation and the GermanJewish symbiosis was destroyed through progressive exclusion (dismissal from jobs, expropriation, disenfranchisement, prohibition of marriage and sexual relations), terrorisation (the 'Kristallnacht' pogrom), stigmatisation (wearing yellow stars), and finally removal and extermination (Staub;66 Abrahams-Sprod 2006). The 'euthanasia' programs pioneered Holocaust technologies, and effected psychological and institutional changes that facilitated it (Dudley and Gale

63 Weindling (2006), 70; Alexander, (1949), 4.

${ }^{64}$ Staub (2003), 29, 303.

65 Staub (2003), 326.

${ }^{66}$ Staub (2003), 291-324. 
2002; Staub $\left.{ }^{67}\right)$. Eichmann acclimatised to genocide through ethnic cleansing of Poles in 1939. When first exposed to bodies of massacred Jews, he reacted with revulsion: however, Nazi ideology, Führer loyalty, his need to belong and careerism, made him continue and ignore his distress, which gradually extinguished (Arendt 1963). Stangl was also drawn into genocide in a stepwise fashion (Sereny 1974). For members of Police Battalion 101, police force career choice and training and increasing Jewish persecution may possibly have aided their desensitisation. ${ }^{68}$ Greek torturers were not selected for sadism but non-deviancy, identification with the political regime, and obedience. Training bound them together through initiation rites, isolation, new values, and elitist language; de-individuation and prevention of thinking; and exposure to frequent, group controlled violence (Gibson and Haritos-Fatouros 1986). Forms of contractual obligation are created, meaningful roles are played, and apparently reasonable rules become binding. Preventing exit, and offering an (ideological) end to justify the means (Staub 2003) are also important. The induction of executioners (Haney et al 1997; Robertson 2006), the 'normalisation' of executions in various countries, and the evolution of terrorists (Bandura 1999) exemplify the same gradualism. In war, indoctrination, humiliation and distancing and the killing or wounding of comrades may provoke explosive retaliation and excitement, a wish to go on killing. ${ }^{69}$ Glover (1999) convincingly documents a stepwise progression in the shift to killing at distance, from the British naval blockade in World War I to the use of the atomic bomb, and details the institutional momentum, moral inertia, diffused responsibility and moral sliding that made it possible. The role of miscommunication, Hobbesian fear and military drift should also not be

67 Staub (2003), 304.

68 Staub (2003), 18-19.

${ }^{69}$ Glover (1999), 47-57. 
underestimated.

\section{Nazi doctors and psychiatrists: motivations and reasons}

Illich and Foucault chart the dangers inherent in medical power and biological knowledge. ${ }^{70}$ (Technical knowledge can facilitate both healing and killing (Lafleur et al 2007)). Unsurprisingly, similar motives and reasons emerge in medical and helping contexts: as noted above, the criteria for 'euthanasia', for example, were ideological ('eugenic', antisemitic, and economic), practical (related to administrative efficiency), and achieved through bureaucratic routine, peer pressure, propaganda and inducements. ${ }^{71}$

At Nuremberg, Nazi doctors and psychiatrists multiplied excuses. These included: following orders, tu quoque, acting for public health or national security, total war demands extreme measures (Proctor 1992), the captives would be killed anyway, prisoners who volunteered for experiments were offered freedom (there was no evidence of this) or might expiate their 'crimes' (that is, minority group status or political beliefs), scientists lacked moral or 'values' expertise, or that the few could be sacrificed for the many (Caplan, ${ }^{72}$ Schmidt 2007, Weindling 2006). The post-war medical trials admitted none of these justifications. Moreover, the claim that the Nazis enforced psychiatric co-operation is a half-truth at best. Despite pressure from peers and superiors, higher ranking and direct perpetrators were seldom simply coerced into transgression. Doctors were not coerced, insane, psychopathic, demonic or incompetent, but frequently pillars of the establishment. ${ }^{73}$ German medicine affiliated to the Nazi

70 Weindling (2006), 5.

${ }^{71}$ Evans (2009), 101.

72 Caplan (2007), 66-70.

${ }^{73}$ Caplan (2007), 65. 
party early ${ }^{74}$ and enthusiastically -it actively welcomed the Nazis (Dudley and Gale 2002) - and in greater numbers than any other professional group (Proctor 1988). The SS was the chief perpetrator organisation, which recruited a high number of professional culprits, especially doctors. Antisemitic ideology, obedience and more authoritarian personality orientation distinguished SS members (Dicks 1972; Merk1 1980; Elms and Milgram 1966; Staub ${ }^{75}$ ). Scientists were not bystanders or pawns: many helped construct Nazi racial policies $^{76}$ which progressively subverted discussions of human experimentation in ethics journals. ${ }^{77}$

German psychiatry, which was somatically focused, statedominated and objectified patients, ${ }^{78)}$ had aided the pursuit of compulsory sterilisation and 'euthanasia'. Eugenics and 'race hygiene' resulted in compulsory sterilisations in several countries. German authorities argued the war sacrificed the best genes, while medicine supported the weak, leaving the worst to proliferate. Purging such 'epidemics' would redeem and regenerate Germany. Many Nazis therefore endorsed medical 'counter-selection' of 'degenerate' individuals and 'useless eaters' (those with various physical, mental and intellectual disabilities, or belonging to certain cultural groups) for euthanasia (Zimbardo; ${ }^{79}$ Weindling; ${ }^{80}$ Gallagher 1990; Lifton 1986, Friedlander 1995; Dudley and Gale 2002). Hitler conceived the German nation as a body to which every true German was indissolubly joined but from which the Jewish 'bacillus', 'virus', 'gangrenous excrescence' were to be

74 Weindling (2006), 5.

75 Staub (2003), 300-01.

76 Proctor (1992), 29.

77 Frewer (2007), 30-45.

78 Pross (1992), 38; Weindling (2007), 7.

79 Zimbardo (2007), 313.

80 Weindling (2006), 99, 158. 
extirpated. Thus genocide was an immune response to illness in the body politic (Koenigsburg 2009). Robert Ritter, psychiatrist with the German National Institute of Health, also viewed 90 per cent of Romani as descendants of the lowest European criminal sub-proletariat, dispatching many for killing. ${ }^{81}$ The supposed subhuman status of live subjects also facilitated coerced experiments. Commitment to public health and alternative medicine contrasted with denial of the social causes of poverty. ${ }^{82}$

Interviewing Nuremberg medical defendants and others, Alexander $(1948,1949)$ concluded that indoctrination, group seduction and sanctioning led to denial of individual responsibility and reality. He speculated that the Nazi regime's enforcement of Blutkitt ('blood putty'), the collective commission of crimes contrary to one's personal values, confirmed extraordinary service in the 'greater cause' or 'sacred mission', proving and reinforcing party allegiance and loyalty. Thus Himmler, famously addressing the SS perpetrators, pardoned them in discharging their 'heroic duty'. Doctors and psychiatrists were often committed Nazis, who 'selected' for national health. For doctors and psychiatrists, the language of eugenics, and the metaphor of surgical extirpation of the ulcer or gangrene of Jewry and other 'degenerates' from the body of German humanity, represented murder as a public service. ${ }^{83}$ Ferocity and hardness replaced Judeo-Christian compassion (Gallagher; ${ }^{84}$ Glover 1999). Among camp doctors, Lifton noted 'doubling', whereby a portion of the self becomes the whole (or 'Auschwitz self'), enabling self-deception and adaptation to

81 Müller-Hill (2007), 59; Weindling (2006), 188-89; Pross (1992), 37.

82 Pross (1992), 38.

83 Friedlander (1995), 11; Graham (1977), 1138-39; Evans (1997), 73.

${ }^{84}$ Gallagher (1990), 198. 
evil environments. Irrespective of this construct's validity (Burleigh 1994; Cohen 2001; Gaita ${ }^{85}$ ), the separation of roles characterised $\mathrm{T} 4$ psychiatrists.

In contrast to the notion of a 'duty to kill', embodied in medical writings of the time (Dudley and Gale 2002) is the motive of venality. As noted above, opportunism and careerism were rampant as the Nazis offered non-Jewish doctors, who did not demur, improved earnings, assets, research opportunities and status as Jewish colleagues were ousted (Proctor 1992). Self-interest-such as financial incentive, career advancement or expropriation - is a common motive in genocide and mass murder. ${ }^{86}$ Zealots also participated eagerly in exterminations, others performed required duties more or less methodically, others again participated reluctantly. ${ }^{87}$

\section{Holocaust bystanders}

Standing by rarely receives sufficient attention, compared with perpetrators, victims and rescuers. Standing by encompasses a number of heterogeneous responses. Some bystanders may be guilt-ridden. Others may fear consequences, be in denial, suppressing uncomfortable knowledge (Speer fits this description), be morally indifferent, or tacitly approve or be complicit in what is occurring. ${ }^{88}$

In the Third Reich, many were passive bystanders or even active participants, boycotting Jewish businesses, benefiting from expropriations of Jewish property or firing Jewish employees, breaking off friendships (Abrahams-Sprod 2006). Deception and obfuscation determined the 'language rules' (Goldhagen 1996, Arendt 1963, Cohen 2001). As noted, Jewish

85 Gaita (1999), 225-26.

86 Staub (2003), 291-324; Baum (2008), 31.

${ }^{87}$ Lifton (1986), 194.

${ }^{88}$ Kershaw (2008), 11. 
and non-Jewish doctors were pitted against each other. The Berlin Psychoanalytic Institute, renamed after Göring, accommodated psychoanalytic concepts to Nazi ideology. ${ }^{89}$ Psychiatrists enhanced their lowly status by accepting the task of identifying and excluding inferior Germans. ${ }^{90}$ German psychiatrist Oswald Bumke asserted in 1945 that though killing people with mental illness was meant to be top secret, 'the sparrows were whistling it from the rooftops' ${ }^{91}$

Research on bystanders and rescuers, compared with perpetrators, is scant. Underpinning bystanding are situational risks that are judged insuperable, and the wish for normality, predictability and social acceptance. Numbing and avoidance of critical thinking are common. Depending on social conditions, bystanders may become temporary perpetrators or rescuers. ${ }^{92}$

Bystanders have power to influence events. To act against Jews, the Nazi leadership needed a reliable substrata of antisemitism. They were apprehensive about popular reactions, but surprised and emboldened by the lack of response, and also popular action against Jews (Hilberg 1961; Dawidowicz 1975; Staub93). Arendt (1994) spoke of 'the empty space' forming around friends and loved ones when the Nazis came to power, in the wave of co-ordination, not yet the pressure of terror. Thus bystanders-nice enough men and women whose moral sense was blunted - made the Holocaust possible (Gryn 1996).

89 Staub (2003), 306-07.

90 Müller-Hill (1988), 22; Friedlander (1995), 123-24.

91 Schmidt (2007), 92.

92 Baum (2008), 153-80.

93 Staub (2003), 309. 
As bystanders, many nations facilitated the Holocaust. Antisemitism existed in western nations. They supported the 1936 Berlin Olympics. American corporations traded with Germany throughout the 1930s (Wyman 1984). In May 1939, the SS St Louis carried 937 Jewish refugees from Hamburg to Cuba, which denied them entry. So, despite appeals, did the United States. Britain, France, Belgium and Holland finally admitted them but subsequently many died in Nazi gas chambers, a consequence of collective international indecision and policy failure regarding Jewish refugees (Thomas and Morgan-Witts, 1974). The Rwandan genocide, ${ }^{94}$ and events in Darfur (among others) also exemplify the effects of standing by.

\section{Motives and reasons for harming: experimental models}

A number of experimental paradigms have modelled elements of perpetrator behaviour, shedding light on Holocaust events as well as later genocides. Stanley Milgram's famous experiments $(1963,1974)$ examined how obedience to authority and conformity might violate people's basic moral beliefs. Milgram was inspired by Asch's conformity experiments. These demonstrated that individual participants' visual comparisons of different line lengths with a reference line could be influenced by peers' false responses. Dissenting peer responses reduced the likelihood of conformity (Asch 1956), but collectivist cultures increased it (Bond and Smith 1996). The Holocaust and contemporaneous Eichmann trial primed Milgram's work.

In New Haven, Connecticut, 1,000 adults aged 20 to 50 years from numerous occupations and educational backgrounds, became unwitting subjects for Milgram's purported study of memory and learning. A white-coated, impassive experimenter ordered them to teach a pleasant volunteer stranger a series of word pairs, using a generator

94 Staub (2003), 341-50. 
that supposedly administered increasingly painful and hazardous shocks when errors were made. The learner, out of sight in another room, was the experimenter's confederate, and though increasingly distressed sounds were pre-recorded and played for each shock level, no shocks were actually given. The experimenter met participants' distress, questioning and wish to discontinue with reassurances that he would assume all responsibility and there was no permanent damage, but increasingly assertive demands that they continue.

Beforehand, Milgram polled professionals' predicted outcomes. All 14 Yale University senior psychology majors believed that very few (average 1.2 per cent) would inflict maximum voltage. Thirty-nine psychiatrists predicted that 0.1 per cent (the 'pathological fringe') would administer maximum voltage, only 4 per cent would reach 300 volts, and most would not exceed 150 volts. The actual results starkly discredited these predictions. Despite personal distress, when pressed, almost two-thirds of participants obeyed to the end (three administered 450 volts). Women and men were equally obedient. The experiment delivered similar results in Princeton, Rome, South Africa, Australia and Munich (where 85 per cent of subjects obeyed until the end) (Milgram 1974). High compliance (6 per cent) occurred when peers complied, the experimenter was adjacent, the learner was in another room, distress sounds were absent, and the warning was only written on the shock generator. Thus avoiding personal sensory awareness of the impact of harmful acts was crucial. Conversely, the experimenter's reduced physical proximity (for example, instructing via phone), the learner's distress sounds or increased proximity (for example, having to hold the learner's arm on a shock plate), conflicting authority (incompatible orders of equal status experimenters), and peer rebellion (observed disobedience of other teachers (actually actors)), reduced obedience. Perhaps non-strangers (family, friends) as learners reducing emotional distance would have 
decreased obedience, while the procedural impersonality of the shock generator facilitated it (Russell and Gregory 2005). Choosing to please rather than confront the experimenter, most participants relinquished personal responsibility and delegated: administering word-pair tests while another participant administered shocks ensured high (93 per cent) compliance. Milgram ${ }^{95}$ associated this with modern bureaucracy, which absolves most from directly destructive actions, employing small numbers of 'the most callous and obtuse' for 'dirty work'. For those who resisted, personalities, feelings of competence, values and (sometimes) group cultures were important (Milgram 1974; Staub 2003).

Albert Bandura et al (1975), purporting to study the effects of punishment on decision-making, derived similar findings. 'Supervisors' who were told to administer electric shocks to unseen subjects who made faulty decisions, increased the intensity of 'shocking' behaviour if responsibility was collective rather than individual, and if recipients were negatively labelled. (No electric shocks were actually given). As performance declined, shock intensities increased, creating further failures that were taken as further evidence of culpability. Self-exonerating justifications prevailed.

The also famous Stanford Prison Experiment (SPE) (Zimbardo 2007; Haney et al 1973) explored the effects of situational variables (including duress and peer pressure) on individual behaviour. Role-playing life in a simulated prison, 24 white middle class young males selected for apparently normal psychological adjustment were randomly assigned to the parts of warders or prisoners. The experiment intentionally reproduced the worst features of prisons, including de-individuation (warders) and dehumanisation (prisoners). Warders received military uniforms, wooden batons and reflective glasses (minimising eye contact), and

95 Milgram (1974), 121-22. 
worked in shifts, returning home off hours. Prisoners donned smocks without underpants, thongs and ankle chains, were assigned identifying numbers, and booked in by actual police co-operating with the experiment at its inception. Loss of personal identity facilitated learned helplessness, with prisoners suffering and accepting sadistic and humiliating treatment from guards. Physical punishments and arbitrary controls included deprivation of privacy, food and sleep, and degrading practices, for example, enforced nudity, and cleaning toilets with bare hands. Some resisted, others became zealous models, many developed uncontrollable crying or disorganised thinking. As with the Nazi doctors (Lifton 1986), guards were zealous, methodical or reluctant, though even the latter failed to challenge the situation. ${ }^{96}$ Inadequate supervision abetted prisoner abuse. The experiment had to be abandoned after six days of the projected fortnight.

Contrary to expectation that individuals facing moral dilemmas would follow their conscience, Milgram's experiment showed that directives from authorities overwhelmed the morality of most individuals who are in no way evil (Milgram 1974; Blass 2002). Zimbardo et al's experiment (and also that by Bandura et al) similarly revealed the importance of individual, situational and systemic factors, including de-individuation and dehumanisation, in understanding institutional abuses (Zimbardo, ${ }^{97}$ Staub 2003).

Taken together, these experiments illustrate the influence of experimentally induced authority, peers, institutional ideology ('the slogan that legitimises the means to attain the goal $^{\prime 98}$ ) and onlookers, on individual behaviours. Ordinary

${ }^{96}$ Zimbardo (2007), 208.

97 Zimbardo (2007), 297-323, 330.

98 Zimbardo (2007), 226. 
people, performing tasks without particular hostility, can act destructively even without physical coercion. Obedience to authority can lead to verbal abuse, sexual assault (strip-search scams provoked by anonymous 'police officers' in American fast-food restaurant chains) or death (for example, doctors' power over nurses in drug ordering, airline pilots' authority over first officers) (Zimbardo 2007, 278ff). Schoolteachers favouring students with blue eyes or brown eyes can transform classrooms into totalitarian, abusive and exclusive environments (Peters 1985). Ron Jones, a teacher in Palo Alto, produced his film 'The Third Wave' in 1967: it showed high school students just how easily fascist behaviour could be 'created' when hierarchies, dressed in appropriate uniforms and insignia, are introduced. This 'situational' paradigm, rather than formal mental illness, repeatedly supports torture and mass murder, as exemplified by the Third Reich's camp guards, Rwandan and former Yugoslavian genocides, terrorists and suicide bombers, ${ }^{99}$ and destructive cults (Jim Jones' People's Temple, Aum Shinrikyo). Role identification and compartmentalisation can produce dire results, as the camp guards who played Bach while they murdered Jews illustrates. ${ }^{100}$

Milgram ${ }^{101}$ believed his results confirmed Arendt's conception of 'the banality of evil'. However, direct authority does not fully explain the sanctioning of harms in everyday situations, where authority is often deliberately diffused, and where ideology is vital (Bandura 1999).

This is not to excuse individuals' reprehensible actions, or to minimise their accountability. But investigators differ in interpreting individual vulnerability to antisocial behaviours and 'moral disengagement'. Bandura (1999) cites parenting

99 Zimbardo (2007), 293; Baum (2008), 76-78.

${ }^{100}$ Gaita (1999), 225-26.

101 Milgram (1974), 6. 
failures, abuse and neglect, early aggression, failure to recognise and cultivate pro-social behaviour, lack of guilt, rumination over personal injustices and retaliation, and lack of perceived efficacy to withstand peer pressure. Zimbardo (2007) argues that these experiments show the potential corruptibility of anyone (including our kin and ourselves) given the right situational and/or systemic (socio-cultural) forces, and difficulty predicting behaviours under stress even with prior knowledge of people's innate, apparently 'normal', dispositions. Baum ${ }^{102}$ responds that this does not account for individual rescuing, and emphasises the predictive importance of personal emotional development.

\section{Motives and reasons for helping}

Social psychology emphasises the power of social situations: under conducive conditions, ordinary decent people can do appalling things. However, the situational paradigm begs the question about why some people behave well, heroically and sometimes repeatedly, in dire situations (Bernstein 2002; Baum 2008). Milgram found a sizeable minority resisted pressure, displaying moral courage and imagination (Bandura 1999). Against self-interest, without expectation of gain, and often in prolonged peril, rescuers of Jews in the Holocaust frequently acted for acquaintances or strangers. Such active behaviour (those honoured by Yad Vashem under-represent those who rescued) was often crucial to outcome in Nazioccupied Europe. Typically, they minimised their contribution, rather than seeing it as heroic. Their actions and motives have been frequently described (for example, Tec 1986; Oliner and Oliner 1988; Paldiel 1988; Fogelman 1994; Gilbert 2002).

Helping can be situationally influenced. For example, the

102 Baum (2008), 4-5, 44-45, 88. 
more people who witness an emergency, the less likely they will help (Darley and Latane 1968). Diffusion of responsibility may explain this, ${ }^{103}$ because helping is more likely when needs are clear, great, impactful and focused, costs are affordable and the behaviour required is socially acceptable. ${ }^{104}$ Time pressure (Darley and Batson 1973) and the prior relationship are also relevant. In Milgram's experiments, as noted, situational determinants, like being personally responsible for and witnessing harms one causes (Milgram 1974; Bandura et al 1975), affected obedience.

But this is notwithstanding the importance of character, competencies in crises, and the capacity of situations to shape character. Crime interveners have a sense of capability founded on training and subjective personal strength (Hudson et al 1981). Steps in help include noticing, understanding the urgency, assuming responsibility, deciding how to help, and implementing one's decision. Like perpetrators and bystanders, rescuers evolve. Contact leads to identification, becoming aware of the human characteristics of those being killed or harmed converts bystanders from passivity to action, and gradual incremental involvement becomes an obsession to rescue. The stories of famous rescuers Oskar Schindler (Keneally 1983) and Raoul Wallenberg show this (Bandura 1999, Staub 2003).

Many Holocaust rescuers and Milgram experiment defiers were deeply connected to and identified with moral parents and families holding strong humanitarian values. Notably, they received less punitive rearing, with closer fathers and more reasoning and explanation (London 1970; Oliner and Oliner 1988; Blass 1991; Blass 1993,105 Tec 1986; Staub,106

103 Zimbardo (2007), 315.

104 Staub (2003), 125, 131.

105 Blass (1993), 40-41, cited in Berkowitz (1999), 249.

106 Staub (2003), 314. 
Baum $\left.^{107}\right)$. While perpetrators have over-developed social identities, rescuers were far more often emotionally mature: independent-minded, emotionally intelligent, having higher self-esteem, subscribing to universal ideals and principles (Baum 2008), and socially responsible. Rescuers differed from bystanders on locus of control, autonomy, risk-taking, social responsibility, tolerance and authoritarianism, empathy, and altruistic moral reasoning (Midlarsky et al 2005). While trait adventurousness characterised some, all rescuers showed courage when confronted with daunting risks. Some belonged to resistance groups, church groups or nations that shaped their responses, though religion did not notably associate with rescuing. Such 'pro-social orientation' (Staub 1995) may be grounded in respect and moral standing, moral principles and identity, and in affective connections and sympathy (Staub 1995; Glover 1999).

The psychology of altruism is relevant here. Altruism is the motivation to help others or for others' welfare without regard to reward or the benefits of recognition. While the payoffs of altruism are hotly debated, helping has its own momentum: the great majority of helpers describe the experience as positive, while conversely people whose lives are more satisfying feel they have more to give others. Research shows that materialistic-competitive goals (wealth, career success, power) are inimical to helping, though not other personal goals (for example, support and security, personal growth, competence, control). ${ }^{108}$

Whole cultures of rescue confronted Nazism, as in Denmark and Bulgaria, and Italy and Hungary before German takeovers in 1943 and 1944 respectively. National

107 Baum (2008), 90-91, 185.

108 Staub (2003), 145-56. 
leadership [and internal political struggles] prevented Bulgarian Jews being deported. Some members of the German Confessing Church, Holland's Antirevolutionary Church, and various Italian and French villages exemplify resistance (as discussed in Colin Tatz's chapter in this volume). In Le Chambon-sur-Lignon, descendants of persecuted Protestant Huguenots led by their pastor and his wife, hid thousands of Jews from the Nazis (Sauvage 1989; Baum ${ }^{109}$ ). Relatives and institutions that protested killing of people with mental, physical and intellectual disabilities acted similarly. Against German efficiency, incorruptibility and obedience, divergent civic traditions (of freedom and equal rights in Denmark, and unpunctuality and inefficiency in Italy) may also have contributed to this outcome (Glover, 1999). At a macropolitical level, realpolitik may determine whether people or nations intervene in oppression or aggression (for example, European nations deciding whether to stop Hitler before World War II). However, membership and memory of minority group status, pro-social orientation, and leadership all contribute to outcomes in national and whole-cultural situations.

\section{Preventing mass human rights violations: where is the engine-room?}

The Holocaust contains individual, situational and social determinants, and (in)humanity arises from ordinary psychological, situational and socio-cultural processes and their evolution into extreme forms. Yet should preventive approaches to mass human rights violations target the level of individual frailty and transgression, or institutional, communal, socio-cultural and national influences? How to address situational factors in facilitating such abuses?

It is a paradox that individuals rather than groups are generally held legally accountable for mass human rights

109 Baum (2008), 205-06. 
violations, yet locating the prime cause of such violations in individual frailty and pathology seems misconceived. Moral actions while remaining the actor's personal responsibility presuppose wider influences (Bandura, 1999; Zimbardo, 2007; Staub, 2003). Research meta-analyses reveal the power of social situations on behaviour is robust, yet criminal justice systems rarely address this. ${ }^{110}$ While individual perpetrators played key roles, the role of German society and nation was absolutely crucial, for example, in accepting Hitler and not resisting antisemitic policies. Virtually every German institution, occupational group or profession contributed voluntarily (usually enthusiastically) to the 'Final Solution', turning their own traditional ethical protocols upside down (Higgins 2006). The effect of this inertia on further Nazi programming has been noted.

Because humans are herd animals, most will do what the herd is doing. Most will manifest as 'saints' or 'sinners' according to the health or breakdown of those communal, societal and political forms of association with which they identify. This suggests there may be value intervening at a number of levels. Educational programs that seek to influence the moral awareness and development of individual children and adults about racism and social inclusion are of potentially great significance, as is the preservation of the moral resources-respect, sympathy and friendship-and cultivation of a moral identity and imagination, in promoting helping and resistance. Pre-eminently, paying attention to these wider determinants and preventing the decline of social and national institutions that preserve civility constitutes a crucial arena for genocide prevention (Higgins 2003; Higgins 2006).

\section{Acknowledgements}

110 Zimbardo (2007), 321. 
Michael Dudley and Fran Gale thank Winton Higgins, Alan Rosen, and Colin Tatz for suggestions about the argument, content and style.

\section{References}

Abrahams-Sprod, M (2006), 'Life Under Siege: The Jews of Magdeburg under Nazi rule', PhD thesis, University of Sydney, Sydney.

Adams, G, Balfour, D (2004), 'Human rights, the moral vacuum of modern organisations, and administrative evil', in Campbell, T and Miller, S (eds) Human Rights and the Moral Responsibilities of Corporate and Public Sector Organisations, chapter 11, 205-21, Alphen aan den Rijn, Kluwer Academic.

Adorno, T (1955, reprinted 1967), Prisms, London, MIT Press.

Alexander J C, with Jay, M, Giesen, B, et al (2009),

Remembering the Holocaust: A debate. Oxford, Oxford University Press.

Alexander, L (1948), ‘War crimes: Their socio-psychological aspects', American Journal of Psychiatry, 105, 170-77.

Alexander, L (1949), 'Medical science under dictatorship', New England Journal of Medicine, 241 (2), 39-47.

Allport, G W (1954), The Nature of Prejudice, Reading MA, Addison-Wesley.

Amnesty International (1980), Testimony on Secret Detention

Camps in Argentina, London, Amnesty International Publications.

Annas, G, Grodin, M (eds) (1992), The Nazi Doctors and the

Nuremberg Code, New York, Oxford University Press.

Arendt, H (1963, revised edition 1968), Eichmann in Jerusalem:

A Report on the banality of evil, New York, Viking, .

Arendt, Hannah, (1994), Essays in Understanding, 1930-1954 (J

Kohn, ed), New York, Harcourt, Brace and Co, 10-11.

Arendt, Hannah (1966), Introduction to Naumann, B, Auschwitz, New York, Praeger, xxiv.

Asch, S E (1956), 'Studies of independence and conformity: A minority of one against a unanimous majority', Psychological Monographs, 70 (whole of no 416). 
Baldwin, P (ed) (1990), Reworking the Past: Hitler, the Holocaust and the historians' debate, Boston, Beacon Press.

Bandura, A (1999), 'Moral Disengagement in the Perpetration of Inhumanities', Personality and Social Psychology Review, 3 (3), 193-209.

Bandura, A, Underwood, B, Fromson, M E (1975), 'Disinhibition of aggression through diffusion of responsibility and dehumanisation of the victims', Journal of Research in Personality, 9, 253-69.

Bankier, D (1992), The Germans and the Final Solution: Public opinion under Nazism, Oxford and Cambridge MA, Blackwell.

Bauer, Y (2001), Rethinking the Holocaust, New Haven, Yale University Press.

Baum, S K (2008), The Psychology of Genocide: Perpetrators, bystanders and rescuers, New York, Cambridge University Press.

Bauman, Z (1989), Modernity and the Holocaust, Ithaca NY, Cornell University Press.

Baumeister, R F, Campbell, W K (1999), 'The intrinsic appeal of evil: sadism, sensational thrills, and threatened egotism', Personality and Social Psychology Review, 3 (3), 210-21.

Berkowitz, L (1999), 'Evil is more than banal: situationism and the concept of evil'. Personality and Social Psychology Review, 3 (3), 246-53.

Bernard, V, Ottenberg, P, Redl, F (1965), 'Dehumanisation: a composite psychological defense in relation to modern war', in Schwebel, M (ed) Behavioural Science and Human Survival, Palo Alto CA, Science and Behavior Books, 64-82.

Bernstein, R (2002), Radical Evil: A philosophical interrogation, Cambridge UK, Polity Press.

Blass, T (1991), 'Understanding behavior in the Milgram obedience experiment: the role of personality, situations, and their interactions', Journal of Personality and Social Psychology, 60, 398-413.

Blass, T (1993), 'Psychological perspectives on perpetrators of 
the Holocaust: the role of situational pressures, personal dispositions, and their interactions', Holocaust and Genocide Studies, 7, 30-50.

Blass, T (2002), 'The man who shook the world', Psychology Today, March/April, 69-74.

Bloche, G, Marks, J (2005), 'When doctors go to war', New England Journal of Medicine, 352, 3-6.

Bock, G (1997), 'Sterilisation and "medical" massacres in National Socialist Germany: ethics, politics and the law', in Berg, M, Cocks, G (eds) Medicine and Modernity: Public health and medical care in nineteenth and twentieth-century Germany, German Historical Institute, Washington DC, and Cambridge University Press, 149-72.

Bond, R, Smith, P B (1996), 'Culture and Conformity: A MetaAnalysis of Studies Using Asch's (1952b, 1956) Line Judgment Task', Psychological Bulletin, 119 (1), 111-37.

Browning, C (1998), Ordinary Men: Reserve Police Battalion 101 and the Final Solution in Poland, [2nd edn], New York, Harper Collins.

Browning, C R (2004). The Origins of the Final Solution: The evolution of Nazi Jewish policy, September 1939 - March 1942, Lincoln, University of Nebraska Press.

Bullock, A (1992), Fanaticism and Calculation, Hitler and Stalin: Parallel lives, New York, Knopf.

Burleigh, M (1994), Death and Deliverance: 'Euthanasia' in Germany ca. 1900--1945. Cambridge, Cambridge University Press.

Caplan, A (2005), 'Editorial: The misuse of the Nazi analogy', Science, 22 July, 535. DOI 10.1126/science 1115437.

Caplan, A (2007), 'The ethics of evil: the challenge and lessons of Nazi medical experiments', in Lafleur, W R, Böhme, G, Shimazono, S (eds), Dark Medicine: Rationalising unethical medical research, Bloomington, Indiana University Press, 63-72.

Card, C (2002), The Atrocity Paradigm: A theory of evil, New York/London, Oxford University Press.

Cesarani, D (2006), Becoming Eichmann: Rethinking the life, 
crimes, and trial of a desk murderer, Cambridge MA, Da Capo Press.

Cohen, S (2001), In Denial: Knowing about atrocities and suffering Cambridge UK, Polity/Blackwell.

Council for International Organizations of Medical Sciences and World Health Organization (1993), International Ethical Guidelines for Biomedical Research Involving Human Subjects, Geneva.

Darley, J M, Batson, C D (1973), 'From Jerusalem to Jericho: a study of situational variables in helping behavior', Journal of Personality and Social Psychology, 27, 100-08.

Darley, J M, Latane, B (1968), 'Bystander intervention in emergencies: diffusion of responsibilities', Journal of Personality and Social Psychology, 8, 377-83.

Dawidowicz, L S (1975), The War Against the Jews: 1933-1945, New York, Holt, Rinehart and Winston.

Des Pres, T (1976), The Survivor: An anatomy of life in a death camp, New York, Oxford University Press.

Dicks, H (1972), Licensed Mass Murder: A socio-psychological study of some SS killers, London, Sussex University Press.

Dudley, M, Gale, F (2002), 'Psychiatrists as a moral community? Psychiatry under the Nazis and its contemporary relevance', Australian and New Zealand Journal of Psychiatry, 36, 585-94.

Ehrenfreund, N (2007), The Nuremberg Legacy: How the Nazi war crimes trials changed the course of history, New York, Palgrave Macmillan.

Elms, A, Milgram, S (1966), 'Personality characteristics associated with obedience and defiance toward authoritative commands', Journal of Experimental Research in Personality, 2, 292-89.

Ericksen, Robert (2012), Complicity in the Holocaust: Churches and universities in Nazi Germany, New York, Cambridge University Press.

Evans, R J (2006), The Third Reich in Power, 1933-1939. Penguin, London. 
Evans, R J (2009), The Third Reich at War, London, Penguin.

Evans, R J (1997), 'In search of German Social Darwinism', in Berg, M, Cocks, G (eds), Medicine and Modernity: Public health and medical care in nineteenth and twentieth-century Germany, Washington DC, Cambridge University Press and German Historical Institute, 55-80.

Evans, R J (2004), The Coming of the Third Reich, London Penguin.

Fiske, S T, Harris, L T, Cudy, A T C (2004), ‘Why ordinary people torture enemy prisoners', Science (Policy Forum) 3006, 1482-83.

Fiske, S T (2003), Social Beings, New York. Wiley.

Fogelman, E (1994), Conscience and Courage: Rescuers of Jews during the Holocaust, New York, Doubleday.

Freedman, R (2010) (director), 'The Wrong Side of the Bus', a documentary film about Sid Bloch and Apartheid, 2010.

Frewer, A (2007), 'Medical research, morality, and history: The German journal 'Ethik' and the limits of human experimentation', in Lafleur, W R, Böhme, G, Shimazono, S, Dark Medicine: Rationalising unethical medical research, Bloomington, Indiana University Press, 30-45.

Friedlander, H (1995), The Origins of Nazi Genocide: From euthanasia to the Final Solution, Chapel Hill NC, University of North Carolina Press.

Friedländer, S (2007), The Years of Persecution: Nazi Germany and the Jews 1933-1939, Phoenix, Orion, London, (original edition, Weidenfeld and Nicolson, 1997).

Gaita, R (1999), A Common Humanity, Melbourne, Melbourne University Press.

Gallagher, H G (1990), By Trust Betrayed: Patients, physicians and the licence to kill in the Third Reich, revised ed, Arlington VA, Vandermere Press.

Gibson, J T, Haritos-Fatouros, M (1986), 'The Education of a Torturer', Psychology Today, November, 50-58.

Gilbert, M (2002), The Righteous: The unsung heroes of the Holocaust, Chatham, Kent, Doubleday.

Glas, G (2006), 'Elements of a phenomenology of evil and 
forgiveness', in Potter, N N (ed), Trauma, Truth and Reconciliation: Healing damaged relationships, New York, Oxford University Press, 171-202.

Glover, J (1999), Humanity: A moral history of the twentieth century, New Haven, Yale University Press.

Goldhagen, D J (1996), Hitler's Willing Executioners: Ordinary Germans and the Holocaust, New York, Knopf.

Graham, L R (1977), 'Science and values: the eugenics movement in Germany and Russia in the 1920s', American Historical Review, 82, 1133-64.

Grodin, M (1992), 'Historical origins of the Nuremberg Code', in Annas, G, Grodin, M (eds), The Nazi Doctors and the Nuremberg Code,' New York, Oxford University Press, 12148.

Grodin, M, Annas, G (2007), 'Physicians and torture: lessons from the Nazi doctors', International Review of the Red Cross, 89, September, 635-54.

Grossman, D (1996), On Killing: The psychological cost of learning to kill in war and society, Boston, Little, Brown and Co.

Gryn, H (2000), Chasing Shadows: Memories of a vanished world, London, Viking.

Halm, Albert (ed) (1985), The Gift of Life, Sydney, Australian Association of Jewish Holocaust Survivors, 95-100.

Hamilton, V L, Sanders, J (1999), 'The second face of evil: wrongdoing in and by the corporation', Personality and Social Psychology Review, 3 (3), 222-33.

Hanauski-Abel, H (1996), ‘Not a slippery slope or sudden subversion: German medicine and national socialism in 1933', British Medical Journal, 7 December, 313, 1453-63.

Haney, C (1997), 'Violence and the capital jury: mechanisms of moral disengagement and the impulse to condemn to death', Stanford Law Review, 49, 1447-86.

Haney, C, Banks, W P, Zimbardo, P G (1973), 'Interpersonal dynamics in a simulated prison', International Journal of Criminology and Penology, 1, 69-97.

Haslam, N, Bain, P, Douge, L, Lee, M, Bastian, B (2005), 'More 
human than you: attributing humanness to self and others', Journal of Personality and Social Psychology, 89, 93750.

Higgins, W (2003), Journey into Darkness, Sydney, Brandl \& Schlesinger.

Higgins, W (2006), 'Could it happen again? The Holocaust and the national dimension', in Tatz, $\mathrm{C}$ et al, (eds.), Genocide Perspectives III: Essays on the Holocaust and other genocides, Sydney, Brandl \& Schlesinger with the Australian Institute for Holocaust and Genocide Studies, 54-77.

Hilberg, R (1961), The Destruction of the European Jews, New York, Harper and Row.

Hudson, T L, Ruggiero, M, Conner, R, Geis, G (1981), 'Bystander intervention into crime: a study based on naturally occurring episodes', Social Psychology Quarterly, 44 (1), 14-23.

Johnson, E, Reuband, K H (2005), What We Knew: Terror, mass murder, and everyday life of Nazi Germany, New York, Basic Books.

Karpinski, J (2004), BBC Radio 4 interview with Brigadier General Janis Karpinski, 15 June 15.

Karpinski, J (with Strasser, S) (2005), One Woman's Army: The commanding general at Abu Ghraib tells her story, New York, Miramax Press.

Kater, M (1997), 'The Sewering scandal of 1993 and the German medical establishment', in Berg, M, Cocks, G (eds) Medicine and Modernity: Public health and medical care in nineteenth and twentieth-century Germany, Washington DC, Cambridge University Press and German Historical Institute, 213-34.

Keen, S (2004), Faces of the Enemy: Reflections on the hostile imagination (original edition, 1991), San Francisco CA, Harper San Francisco.

Kelman, H C, Hamilton, V L (1989), Crimes of Obedience: Towards a social psychology of authority and responsibility, New Haven CT, Yale University Press.

Keneally, T (1983), Schindler's Ark, UK, Coronet Books.

Kershaw, I (2000), The Nazi Dictatorship Problems and 
Perspectives of Interpretation, London, Arnold Press.

Kershaw, I (2008) "“Working towards the Führer": Reflections on the nature of Hitler's dictatorship', in Kershaw, I, Hitler, the Germans and the Final Solution, Jerusalem, International Institute for Holocaust Research, Yad Vashem, and New Haven, Yale University Press, 29-48 (originally published 1997).

Kilham, W, Mann, L (1974), 'Level of destructive obedience as a function of transmitter and executant roles in the Milgram obedience paradigm', Journal of Personality and Social Psychology, 29, 696-702.

Koenigsburg, R (2009), Hitler's ideology: embodied metaphor, fantasy and history, Charlotte NC, Information Age Publishing.

Kubarych, T S (2004), 'Self-deception and Peck's analysis of evil', Philosophy, Psychiatry, \& Psychology, 12.3, 247-55.

Lafleur, W R, Böhme, G, Shimazono, S (2007), Dark Medicine: Rationalising unethical medical research, Bloomington, Indiana University Press.

Lerner, M (1980), The Belief in a Just World: A fundamental delusion, New York, Plenum.

Levi, P (1987), The Drowned and the Saved, New York, Summit.

Lie, R K, Emanuel, E, Grady, C, Wendler, D (2004), 'The standard of care debate: the Declaration of Helsinki versus the international consensus opinion', Journal of Medical Ethics 30 (2), 190-93. doi:10.1136/jme.2003.006031. PMID 15082816

Lifton, R (1986), The Nazi Doctors: Medical killing and the psychology of genocide, New York, Basic Books.

London, P (1970), 'The rescuers: motivational hypothesis about Christians who saved Jews from the Nazis', in Macauley, J, Berkowitz, L (eds), Altruism and helping behavior, New York, Academic Press.

Lurie, P, Wolfe, S M (1997), 'Unethical trials of interventions to reduce perinatal transmission of the human immunodeficiency virus in developing countries', New 
England Journal of Medicine, 337 (12), 18 September, 853-56. Macklin, R (1999), Against Relativism, New York, Oxford University Press.

Mandler, G (2002), 'Psychologists and the Nazi socialist access to power', History of Psychology, 5 (2), 190-200.

Markusen, E (1997), 'Professions, professionals, and genocide', in Charny, I (ed) Genocide: A critical bibliographic review, vol 4, Facts on File, Institute on the Holocaust and Genocide, New York/Oxford, 264-98.

Maslow, A (1987), Motivation and Personality, (3rd edn, original published 1954), New York, Harper and Row.

Mason, T (1989), 'Intention and Explanation: A Current Controversy about the Interpretation of National Socialism', in Marris, M (ed), The Nazi Holocaust Part 3, The 'Final Solution': The Implementation of Mass Murder, vol 1, Westpoint CT, Mecler, 3-20.

McFarland-Icke, B R (1999), Nurses in Nazi Germany: Moral choice in history, New Jersey, Princeton University Press.

McGovern, W M (1973), From Luther to Hitler, New York, Houghton Mifflin.

Merkl, P (1980), The Making of a Stormtrooper, Princeton NJ, Princeton University Press.

Michman, D (2010), 'Despite the importance and centrality of antisemitism, it cannot serve as the exclusive explanation of murder and murderers': David Bankier's (1947-2010) path in Holocaust research'. Translated from the Hebrew by Stephanie Nakache, Jerusalem, Yad Vashem Studies 38, 1, 15-45, also at

http://www1.yadvashem.org/yv/en/about/institute/stu dies/issues/38-1/michman.pdf accessed 18 July 2011.

Midlarsky, E, Jones, S E, Corley, R P (2005), 'Personality correlates of heroic rescue during the Holocaust', Journal of Personality, 73 (4), August, 907-34.

Miles, S H (2004), 'Abu Ghraib: its legacy for military medicine', Lancet, 364, 725-29.

Milgram, S (1963), 'Obedience to authority', Journal of Abnormal and Social Psychology, 67, 371-78. 
Milgram, S (1974), Obedience to Authority: An experimental view, New York, Harper and Row.

Mommsen, H (1997), 'Cumulative radicalisation and progressive self-destruction as structural determinants of the Nazi dictatorship', in Kershaw, Ian and Lewin, Moshe (eds), Stalinism and Nazism: Dictatorships in comparison, Cambridge, Cambridge University Press.

Moore, B (1966), Social Origins of Dictatorship and Democracy: Lord and peasant in the making of the modern world, Boston, Beacon Press.

Moreno, J D (2007), 'Stumbling towards bioethics: human experiments policy and the early cold war', in Lafleur, $\mathrm{W}$ R, Böhme, G, Shimazono, S, Dark Medicine: Rationalising unethical medical research, Bloomington, Indiana University Press, 138-46.

Müller-Hill, B (1988), Murderous Science: Elimination by scientific selection of Jews, Gypsies and others, Germany 19331945, Oxford, Oxford University Press.

Müller-Hill, B (2007), 'The Silence of the Scholars', in Lafleur, W R, Böhme, G, Shimazono, S, Dark Medicine: Rationalising unethical medical research, Bloomington, Indiana University Press, 57-62.

Neumann, F (1967), Behemoth: The structure and practice of National Socialism 1933-44, (second ed), London, Frank Cass \& Co.

Noll, R (1997), The Aryan Christ: The secret life of Carl Jung, London, Macmillan.

Novick, P (2000), The Holocaust and Collective Memory: The American experience, London, Bloomsbury.

Nuffield Council on Bioethics (2005), The ethics of research related to healthcare in developing countries: A follow-up discussion paper, accessed from http:/ / www.nuffieldbioethics.org 26 Oct 2010. London: Nuffield Council on Bioethics.

Oliner, S P, Oliner, P M (1988), The Altruistic Personality: Rescuers of Jews in Nazi Europe, New York, Free Press. 
Paldiel, M (1988), 'The altruism of Righteous Gentiles', Holocaust and Genocide Studies, 3, 187-96.

Peacock, M (2009), Killer Company, Sydney, HarperCollins.

Peck, M S (1982), People of the Lie: The hope of healing human evil, New York, Simon and Schuster.

Perley, S, Fluss, S S, Bankowski, Z, Simon, F (1992), 'The

Nuremberg Code: an international overview', in Annas, G, Grodin, M (eds), The Nazi Doctors and the Nuremberg Code, New York, Oxford University Press, 149-73.

Peters, W (1985), A Class Divided Then and Now, (expanded edition, original 1971), New Haven CT, Yale University Press. See also the PBS Frontline documentary 'A Class Divided', available online at www.pbs.org/wgbh/pages/frontline/shows/divided

Pina e Cunha, M, Rego, A, Clegg, S (2010), 'Obedience and evil: From Milgram and Kampuchea to normal organizations', Journal of Business Ethics, DOI 10.1007/s10551-010-0510-5.

Power, S (2002), 'A Problem from Hell': America and the age of genocide, New York, Basic Books.

Proctor, R (1992), 'Nazi doctors, Racial medicine and human experimentation', in Annas, G, Grodin, M (eds), The Nazi Doctors and the Nuremberg Code, New York, Oxford University Press, 17-31.

Pross, C (1992), 'Nazi doctors, German medicine and historical truth', in Annas, G, Grodin, M (eds), The Nazi Doctors and the Nuremberg Code, New York, Oxford University Press, 32-52.

Rennie, S (2008), 'The FDA ditches the Declaration of Helsinki', Global Bioethics Blog, 6 May, at http://globalbioethics.blogspot.com/2008_05_01_archive. html accessed 24/11/10).

Reverby, S (2009), Examining Tuskegee: The infamous syphilis study and its legacy, University of North Carolina Press.

Richard, F D, Bond, D F (Jnr), Stokes-Zoota, J J (2003), ‘One hundred years of social psychology quantitatively described', Review of General Psychology, 7, 331-63.

Richards, H (2006), 'We knew nothing about this', Times 
Higher Education, 8 September., http://www.timeshighereducation.co.uk/story.asp?story Code $=205253 \&$ sectioncode $=26$ accessed 14 February 2010. Robertson, G (2006), Crimes against Humanity: The struggle for global justice, 3rd ed, Melbourne, Penguin.

Rosen, A (2011), 'Are we letting bad guys like Gaddafi off the hook?', National Times (Fairfax Press, Sydney Morning Herald, The Age), 23 March.

Russell, N, Gregory, R (2005), 'Making the Undoable Doable: Milgram, the Holocaust, and Modern Government', American Review of Public Administration, 35 (4), December, 327-49. Doi 10.1177/0275074005278511.

Sauvage, P (1989), 'Weapons of the spirit: the astonishing story of a unique conspiracy of goodness' [film], Friends of the Le Chambon Foundation, Los Angeles.

Schlink, B (2009), Guilt about the Past, St Lucia, University of Queensland Press.

Schmidt, U (2004, second edn 2006), Justice at Nuremberg: Leo Alexander and the Nazi doctors' trial, Basingstoke UK, Palgrave Macmillan.

Sereny, G (1974), Into That Darkness: From mercy killing to mass murder, London, Pimlico.

Sereny, G (1996), Albert Speer: His battle with truth, London, Picador.

Sereny, G (2000), The German Trauma: Experiences and reflections 1938-2001, London, Penguin.

Sharma, D C (2004), 'India pressed to relax rules on clinical trials. Drug companies claim changes are essential, but critics fear Indian patients will become guinea pigs', Lancet, 8 May, 363 (9420), 1528-29.

Silove, D (2000), 'A conceptual framework for mass trauma: implications for adaptation, intervention and debriefing', in Raphael, B, Wilson, J (eds), Psychological Debriefing: Theory, Practice and Evidence, Cambridge, Cambridge University Press, 337-350.

Social Medicine Portal (2008), ‘FDA abandons Declaration of 
Helsinki for international clinical trials', 1 June, 2008, http:// www.socialmedicine.org/2008/06/01/ethics/fdaabandons-declaration-of-helsinki-for-international-clinicaltrials/ accessed 31/12/10.

Soelle, D (2001), The Silent Cry: Mysticism and resistance, Minneapolis, Fortress Press.

Sontag, S (2003), Regarding the Pain of Others, London, Penguin.

Staub, E (1989), The Roots of Evil: The origins of genocide and other group violence, New York, Cambridge University Press.

Staub, E (2003), The Psychology of Good and Evil: Why children, adults and groups help and harm others, Cambridge UK, Cambridge University Press.

Steinmetz, G (1997), 'German exceptionalism and the origins of Nazism: the career of a concept', in Kershaw, Ian and Lewin, Moshe (eds), Stalinism and Nazism: Dictatorships in comparison, Cambridge, Cambridge University Press, 25184 .

Tec, N (1986), When Light Pierced the Darkness: Christian rescue of Jews in Nazi-occupied Poland, New York, Oxford University Press.

Thomas, G, Morgan-Witts, M (1974), Voyage of the Damned, New York, Stein and Day; Weindling, P J (2006), Nazi Medicine and Nuremberg Trials: From medical war crimes to informed consent, Basingstoke UK, Palgrave Macmillan.

Williams, J R (2008), 'The Declaration of Helsinki and public health, Bulletin of the World Health Organisation, 86, August, 650-52.

Winau, R (2007), 'Experimentation on humans and informed consent: how we arrived where we are', in Lafleur, W R, Böhme, G, Shimazono, S, Dark Medicine: Rationalising unethical medical research, Bloomington, Indiana University Press, 46-56.

Wyman, D S (1984), The Abandonment of the Jews: America and the Holocaust, 1941-1945, New York, Pantheon.

Zimbardo, P (2007), The Lucifer Effect: How good people turn evil, London, Rider. 